\title{
PENEGAKAN HUKUM TERHADAP PELAKU PENYELUNDUPAN MANUSIA KE INDONESIA
}

\author{
Yasmirah Mandasari Saragih", Ahmad Zaharuddin Sani B. Ahmad Sabri², \\ Roziya $\mathrm{Abu}^{3}$ \\ ${ }^{1}$ Universitas Pembangunan Panca Budi, Medan, Indonesia \\ ${ }^{2}$ School of Language, Civilization and Philosophy, Universiti Utara Malaysia \\ ${ }^{3}$ Faculty of Information Management Universiti Teknologi MARA, Malaysia \\ yasmirahmandasari@gmail.com
}

\begin{abstract}
Abstrak
Tujuan penelitian ini adalah untuk menganalisis pengaturan hukum terhadap imigran ilegal di Indonesia dan analisis mengenai penanganan yang dilakukan Pemerintah Republik Indonesia terhadap adanya imigran ilegal. Metode penelitian ini menggunakan yuridis normatif. Problem imigran gelap tidak hanya dipandang dari aspek hukum secara normatif, namun lebih dari itu persoalan imigran adalah persoalan nasib manusia yang ingin mendapatkan kehidupan yang layak dan bermartabat di negara lain. Jika inilah yang menjadi persoalan maka persoalannya bisa dipahami dari aspek kemanusiaan. Tapi jika persoalan imigran adalah dilakukan oleh orang-orang yang akan melakukan kejahatan dan sejenisnya,maka inilah yang perlu mendapatkan penanganan hukum yang serius sampai akhirnya pada proses deportasi ke Negara asal. Faktor adanya imigran gelap ini adalah karena posisi geografis Indonesia yang strategis sebagai penghubung antar kawasan Asia Tengah dan Timur Tengah dengan Australia dalam pergerakan arus migrasi ini menyebabkan Indonesia menjadi wilayah transit yang banyak dilalui oleh para imigran gelap tersebut. Indonesia yang bentuk negaranya adalah kepulauan secara geografis memiliki banyak pintu masuk: bandara, pelabuhan, batas, darat dan perairan. Selain itu, Indonesia yang juga memiliki garis pantai yang sangat panjang, dan merupakan wilayah yang terletak pada posisi silang jalur lalu lintas. Perhatian Pemerintah Indonesia yang cukup besar dalam penanganan imigran gelap seperti pemberian fasilitas tempat tinggal sementara. Adanya pantai selatan menjadi salah satu daerah sangat strategis di Indonesia yang dipakai tempat transit para imigran gelap untuk menyebrang ke Pulau Christmas, Australia. Hal itu sehubungan, jarak antara pantai dan lain-lain merupakan faktor pendukung lain dipilihnya Indonesia sebagai wilayah transit.
\end{abstract}

Kata kunci : Penegakan Hukum; Penyeludupan Manusia; Imigran Gelap. 


\title{
LAW ENFORCEMENT AGAINST PERPETRATORS OF PEOPLE SMUGGLING INTO INDONESIA
}

\begin{abstract}
The purpose of this study is to analyze the legal arrangements against illegal immigrants in Indonesia and an analysis of the handling carried out by the government of the Republic of Indonesia against illegal immigrants. This research method uses normative juridical. The problem of illegal immigrants is not only seen on the legal aspects of normative, but more than that, immigrant issue is the issue of human destiny who want to earn a decent and dignified life in another country. If that is the issue, the question could be understood from the humanitarian aspect. But when the problem of immigrants carried out by people who would commit a crime and the like, then this would need to be addressed serious law until the process deportase to the country of origin. Factor presence of illegal immigrants is due to the geographical position of Indonesia strategicly as a liaison between Central Asia and the Middle East to Australia in which movement of migration flows contribute Indonesia become a transit area traversed by many illegal immigrants. Indonesia which is an archipelago country geographically has many entrances: airports, ports, borders, land and sea. In addition, Indonesia also has a very long coastline, and a region which is located at the intersection of traffic lanes. Indonesian government's considerable attention to the handling of illegal immigrants such as the provision of temporary shelter facilities. The existence of south coast became one of the strategic areas in Indonesia that is used as a transit point for illegal migrants crossing to Christmas Island, Australia. Another thing, the distance between the beach and others is another supporting factor that Indonesia is chosen as a transit area.
\end{abstract}

Keywords: Law Enforcement; People Smuggling; Illegal Immigrant. 
e-ISSN : 2621-4105

\section{A. PENDAHULUAN}

Keberadaan pengungsi merupakan suatu persoalan yang akan selalu ada dalam peradaban manusia. Hal ini sebagai konsekuensi adanya naluriah manusia yang akan selalu mencari kenyamanan dalam hidupnya, dan menghindar dari adanya rasa takut, yang sangat yang dapat mengancam keselamatan. Ancaman itu dapat ditimbulkan oleh faktor alam maupun faktor perbuatan manusia lainnya. Yang termasuk ancaman dalam kategori faktor alam adalah "bencana alam, sedangkan yang termasuk perbuatan manusia seperti perang, kerusuhan dan sebagainya". Dahulu, dorongan utama dilakukannya migrasi pada masa itu secara umum berasal dari naluri alamiah umat manusia untuk mencari tempat tinggal atau daerah bermukim yang dapat memberikan keamanan dan kenyamanan. Sejarah mencatat, bangsa Canaan (yang sekarang disebut bangsa Palestina) pernah melakukan migrasi dari Asia menuju Eropa, demikian juga yang dilakukan oleh bangsa Romawi di masa kejayaannya dan bangsa-bangsa lainnya. ${ }^{1}$ Pengungsian atau perpindahan penduduk dalam skala besar ini pada awalnya hanya merupakan persoalan domestik suatu negara. Kemudian, karena perpindahan penduduk juga melampui suatu batas negara satu ke negara lainnya, masalah pengungsi akhirnya meluas menjadi persoalan negara-negara di kawasan tertentu dan terakhir dianggap merupakan masalah bersama umat manusia. ${ }^{2}$ Persoalan itu pada akhirnya juga menjadi persoalan yang tidak dapat dihindari oleh pemerintah Indonesia. Sebagai negara yang kerap kali menjadi tujuan bagi para pengungsi untuk mencari perlindungan dan keselamatan diri.

Posisi Indonesia yang terletak di antara dua samudra dan dua benua, menjadikan Indonesia sebagai tempat yang strategis untuk pergerakan dan juga tempat transit pengungsi asing asal benua Asia yang ingin pergi ke Australia. Dalam beberapa tahun terakhir, sesuai data yang diberikan oleh lembaga PBB untuk pengungsi atau United Nations High Commissioner for Refugees (UNHCR), Indonesia telah menerima banyak pengungsi asing baru secara signifikan. Namun, dalam krisis pengungsi global saat ini, dengan setidaknya 79.5 juta orang di seluruh dunia melakukan perpindahan terpaksa, UNHCR bekerja untuk mencari serangkaian solusi lain, termasuk cara-cara sementara bagaimana pengungsi dapat memperoleh kesempatan untuk menjadi mandiri hingga

${ }^{1}$ IOM, Buku Petunjuk Bagi Petugas Dalam Rangka Penanganan Kegiatan Penyelundupan Manusia dan Tindak Pidana yang Berkaitan dengan Penyelundupan Manusia, International Organization for Migration (IOM), Jakarta, 2009, halaman 24.

2 Achmad Romsan, dkk, "Pengantar Hukum Pengungsi Internasional: Hukum Internasional dan PrinsipPrinsip Perlindungan Internasional”, Percetakan Sanic Offset, Bandung, 2003, hal 3. 
e-ISSN : 2621-4105

solusi jangka panjang yang sesuai ditemukan; dan solusi pelengkap seperti beasiswa universitas dan kemungkinan penyatuan keluarga yang difasilitasi Negara. Data per Desember 2020 menyebutkan bahwa 13.742 orang telah terdaftar di UNHCR Indonesia dengan rincian 10.121 orang merupakan pengungsi dan 3.622 orang terdaftar sebagai pencari suaka. ${ }^{3}$

Dalam hal ini banyak negara di dunia umumnya sependapat bahwa migrasi yang dilakukan tidak sesuai dengan peraturan keimigrasian atau migrasi ilegal akan mengakibatkan ancaman terhadap kedaulatan, keamanan, kehidupan sosial dan ekonomi, bahkan juga ancaman terhadap ideologi suatu bangsa. Belum lagi migrasi ilegal bisa dihentikan, telah timbul varian baru yang kini kian mengemuka, yakni penyelundupan manusia (people smuggling), dan perdagangan manusia (human trafficking). ${ }^{4}$

Sudah ada beberapa penelitian sebelumnya yang mengkaji tentang penyelundupan manusia, diantaranya oleh Junef (2020), penelitian tersebut mengkaji tentang bagaimana kebijakan pemerintah RI dalam menanggulangi permasalahan penyelundupan manusia. Permasalahan yang diangkat dalam penelitian tersebut tentang faktor-faktor yang menjadi penyelundupan manusia di Indonesia tetap selalu ada dan bagaiman upaya dari pemerintah dalam menghadapi penyelundupan manusia. Masih adanya tragedi kemanusiaan dan konflik yang terjadi di beberapa negara maenjadi salah satu faktor penyebab terjadinya penyelundupan manusia. Sedangkan upaya yang dilakukan dalam menghadapi penyelundupan manusia lebih kepada tindakan pencegahan melalui kesadaran masyarakat. ${ }^{5}$

Penelitian serupa tentang penyelundupan manusia juga diangkat oleh Silvia (2020) yang lebih banyak mengkaji tentang bagaimana kejahatan penyelundupan manusia sebagai kejahatan transnasional yang telah terorganisir. Penelitian ini mengulas bagaimana kejahatan penyelundupan manusia ini semakin marak dan semakin meluas perkembangannya dengan berbagai lintas negara. Perlunya penegakan hukum yang tegas dalam memberantas kejahatan penyelundupan manusia yang telah berkembang menjadi

${ }^{3}$ https://www.unhcr.org/id/unhcr-di-indonesia, diakses tanggal 25 April 2021

${ }^{4}$ Kusumaatmadja Mochtar, "Pengantar Hukum Internasional”, (Jakarta : Bina Cipta 1976), hal 4.

${ }^{5}$ Muhar Junef, "Kajian Praktik Penyelundupan Manusia di Indonesia”, Jurnal Penelitian Hukum De Jure, 20 (1), 2020, hal 85-102. 
e-ISSN : 2621-4105

lintas negara. Kerjasama antar negara secara bersama-sama dalam memerangi peneyelundupan manusia akan lebih efektif. ${ }^{6}$

Sedangkan Salam (2020) dalam penelitianya yang berjudul "Penegakan Hukum Tindak Pidana Penyelundupan Manusia (People Smuggling) Dalam Hukum Positif Indonesia" lebih fokus meneliti tentang penegakan hukum tindak pidana penyelundupan manusia berdasarkan Undang-Undang Nomor 6 Tahun 2011 tentang Keimigrasian dan Undang-undang Nomor 15 Tahun 2009 tentang Pengesahan Protokol Menentang Penyelundupan Migran Melalui Darat, Laut, Dan Udara. Penelitian ini juga mengkaji tentang kebijakan formulasi di masa yang akan datang untuk menanggulangi tindak pidana penyelundupan manusia di Indonesia. Hasil dari penelitian tersebut menjelaskan bahwa upaya penegakan hukum tindak pidana penyelundupan manusia hingga saat ini belum maksimal karena belum ada undang-undang khusus untuk menangani tindak pidana penyelundupan manusia dan hanya mengacu pada Undang-Undang Keimigrasian. Sedangkan kebijakan formulasi di masa yang akan datang sudah masuk dalam dalam Konsep Rancangan Kitab Undang-undang Hukum Pidana 2019 dimuat dalam Buku II BAB XX Penyelundupan Manusia dalam Pasal 463. Dalam konsep perundang-undangan tersebut masih ditemukan adanya keterbatasan kemampuan hukum pidana, sehingga perlu adanya penyelesaian upaya hokum melalui sarana non-penal. ${ }^{7}$

Penelitian ini melengkapi dari penelitian yang ada sebelumnya yang mengkaji tentang penyelundupan manusia di Indonesia. Perbedaan penelitian ini dibandingkan dengan penelitian sebelumnya adalah tentang bagaimana penanganan Pemerintah Republik Indonesia dalam menangani penyelundupan manusia di Indonesia. Tujuan penelitian ini adalah untuk menganalisis pengaturan hukum terhadap imigran ilegal di Indonesia dan analisis mengenai penanganan yang dilakukan Pemerintah Republik Indonesia terhadap adanya imigran ilegal

\section{B. RUMUSAN MASALAH}

Berdasarkan latar belakang tersebut di atas, maka penulis dapat merumuskan 2 (dua) masalah yaitu:

1. Bagaimana pengaturan hukum terhadap imigran ilegal di Indonesia ?

\footnotetext{
${ }^{6}$ Evi Masrifatin Silvia, "Upaya Penanggulangan Kasus Perdagangan dan Penyelundupan Manusia Sebagai Kejahatan Transnasional Terorganisir “, Journal Inicio Legis 1 (1), 2020, hal 1-17.

${ }^{7}$ Eka Annisa Salam, "Penegakan Hukum Tindak Pidana Penyelundupan Manusia (People Smuggling) Dalam Hukum Positif Indonesia”, Jurnal Pemuliaan Hukum 3 (1) 2020, hal 9-20.
} 
e-ISSN : 2621-4105

2. Bagaimana penanganan yang dilakukan pemerintah Indonesia terhadap keberadaan imigran ilegal di Indonesia?

\section{METODE PENELITIAN}

Dalam penulisan hukum ini penulis menggunakan jenis penelitian hukum normatif yang adalah "metode penelitian hukum yang dilakukan dengan meneliti bahan pustaka atau data sekunder." "Metode penelitian hukum ini dilakukan dengan menggunakan data sekunder yang berupa bahan-bahan hukum yang terdiri dari perjanjian-perjanjian internasional, juga menggunakan bahan-bahan hukum yang diperoleh dari pendapatpendapat para ahli hukum dan pihak yang berwenang baik secara lisan atau tertulis serta buku-buku hukum lainnya yang relevan dengan penelitian ini.

\section{HASIL DAN PEMBAHASAN}

\section{Masalah Pengaturan Hukum Terhadap Imigran Ilegal di Indonesia}

Pertahanan negara merupakan bagian dari fungsi pemerintahan suatu negara yang bertujuan untuk mencapai tujuan nasional. Ancaman yang muncul di batas negara memperlihatkan adanya ancaman yang dapat mengganggu kedaulatan negara. Penyelundupan manusia merupakan ancaman yang kini muncul di perbatasan negara dengan menjadikan Indonesia sebagai negara transit. ${ }^{9}$

Dengan adanya imigran di wilayah teritorial Indonesia, telah menghadirkan permasalahan tersendiri dan signifikan di Indonesia, yaitu timbulnya dampak dibidang ideologi, ekonomi, politik, sosial budaya, keamanan nasional, dan kerawanan keimigrasian, bahkan juga tidak sedikit kasus yang mengindikasikan adanya perdagangan manusia. Disamping itu, permasalahan muncul ketika pemerintah Indonesia tidak tanggap dalam menangani para imigran ilegal itu, Karena Indonesia belum meratifikasi Konvensi Pengungsi Tahun 1951 dan Protokol Opsionalnya tahun 1967 tentang Status Pengungsi, maka pemerintah tak bisa langsung menetapkan status para imigran ilegal tersebut sebagai pencari suaka atau pengungsi. Penentuan status dilakukan oleh UNHCR yang memakan waktu yang lama.

Menurut Undang-Undang (UU) No.6 Tahun 2011 tentang Keimigrasian masih mengelompokan pengungsi dan pencari suaka sebagai imigran ilegal atau imigran yang

${ }^{8}$ Soerjono Soekanto, 2001, “Penelitian Hukum Normatif', Rajawali Pers, Jakarta, halaman 13-14.

9 Suryani, Suhirwan, Rudy A. G. Gultom, "Strategi Pangkalan TNI AL Dumai Dalam Menghadapi Penyelundupan Manusia Di Perbatasan Laut Dumai Dan Selat Malaka”, Jurnal Peperangan Asimetris 4 (3), 2018, hal 61-75. 
e-ISSN : 2621-4105

memasuki wilayah Indonesia tanpa dokumen yang resmi atau tanpa melalui prosedur yang sudah ditentukan oleh UU. Maka itu para pengungsi dan pencari suaka selalu dikenakan tindakan dalam bentuk penahanan selama jangka waktu yang tidak pasti di Rumah Detensi Imigrasi (RUDENIM) yang tersebar di beberapa lokasi di Indonesia. Kondisi seperti ini jelas memprihatinkan, karena mereka pada umumnya tidak pernah bermaksud untuk memasuki wilayah suatu negara tanpa ada dokumen resmi karena memang pada dasarnya sulit untuk para pengungsi memperoleh dokumen imigrasi yang resmi.

Pasal 120 UU Keimigrasian mengatur tentang tindak pidana penyelundupan manusia dengan "ancaman pidana penjara paling singkat lima tahun dan paling lama 15 tahun serta pidana denda paling sedikit Rp. 500 juta dan paling banyak Rp. 1,5 milyar”. Ancaman pidana yang sama juga berlaku untuk percobaan untuk melakukan tindak pidana penyelundupan manusia. Aturan-aturan mengenai tata cara keluar masuknya orang ke Indonesia diatur dalam UU 6/2011. Dalam ketentuan Pasal 8 ayat (1) UU 6/2011, yang menyebutkan: "Setiap orang yang masuk atau keluar wilayah Indonesia wajib memiliki dokumen perjalanan yang sah dan masih berlaku".

Diatur bahwa setiap orang yang masuk maupun yang keluar wilayah Indonesia harus memiliki dokumen perjalanan yang sah dan masih berlaku. Maka dalam hal ini, menurut informasi yang Anda berikan di atas, maka warna negara asing ("WNA") yang Anda sebut sebagai seorang "refugee" atau pengungsi tersebut adalah WNA yang tidak memiliki dokumen perjalanan yang sah, sehingga melanggar ketentuan sebagaimana diatur dalam UU 6/2011.

Pengaturan lebih lanjut mengenai "refugee" atau pengungsi dari negara lain yang masuk ke Indonesia tidak sesuai dengan ketentuan dalam UU 6/2011 dapat dilihat di dalam ketentuan Peraturan Direktur Jenderal Imigrasi Nomor IMI-1489.UM.08.05 Tahun 2010 tentang Penanganan Imigran Ilegal ("Peraturan Dirjen Imigrasi tentang Penanganan Imigran Ilegal"). Dalam peraturan ini, refugee atau pengungsi disebut dengan istilah imigran ilegal. Pasal 1 angka 1 Peraturan Dirjen Imigrasi tentang Penanganan Imigran Ilegal menyebutkan: 
"Dalam peraturan direktur jenderal ini yang dimaksud dengan: imigran ilegal adalah orang asing yang masuk dan atau berada di wilayah indonesia tidak sesuai dengan ketentuan peraturan perundang-undangan”.

Diatur bahwa yang dimaksud dengan imigran ilegal adalah "WNA yang masuk atau berada di Indonesia secara tidak sah, sehingga seharusnya terhadap orang tersebut dikenakan tindakan keimigrasian sebagaimana dimaksud dalam ketentuan Pasal 2 ayat (1) Peraturan Dirjen Imigrasi tentang Penanganan Imigran Ilegal”, yang menyebutkan: "Imigran Ilegal saat diketahui berada di Indonesia dikenakan tindakan keimigrasian".

Yaitu, berupa tindakan pendeportasian (Pasal 75 ayat (2) huruf f UU 6/2011) atau penempatan di tempat penampungan sementara (Ruang Detensi Imigrasi) sebagaimana diatur dalam ketentuan Pasal 83 ayat (1) huruf b dan huruf d UU 6/2011, yang menyebutkan bahwa Pejabat Imigrasi berwenang menempatkan orang asing dalam Rumah Detensi Imigrasi atau Ruang Detensi Imigrasi jika orang asing tersebut yang berada di wilayah Indonesia tanpa memiliki dokumen perjalanan yang sah atau menunggu pelaksanaan deportasi. ${ }^{10}$

Berdasarkan Pasal 75, menyatakan bahwa "setiap pejabat imigrasi dapat melakukan tindakan administratif berupa pencatuman dalam daftar pencegahanatau penangkalan, pembatasan, perubahan, atau pembatalan IzinTinggal, pengenaanbiaya beban, bahkan melakukan deportasi dari wilayah Indonesia (vide Pasal 75 ayat 2 UU No.6 Tahun 2011)". Pejabat Imigrasi yang melakukan tindakan administratif dimaksud, dapat bersandar pada klausul "dugaan" semata, atau menganggap orang asing tersebut tidak memiliki manfaat (asas kemanfaatan) bagi negara Indonesia, berdasarkan asas kebijakan selektif (selective policy priniciple). Jadi dalam halini tidak berlaku asas praduga tidak bersalah (presumption of innocence principle), seperti yang dipahami dalam Hukum Acara Pidana. ${ }^{11}$

Hanya saja, dalam hal imigran ilegal tersebut menyatakan keinginan untuk mencari suaka dan/atau karena alasan tertentu tidak dapat dikenakan pendeportasian, dikoordinasikan dengan organisasi internasional yang menangani masalah pengungsi dan/atau UNHCR untuk penentuan statusnya (Pasal 2 ayat (2) Peraturan Dirjen Imigrasi tentang Penanganan Imigran Ilegal).

\footnotetext{
${ }^{10}$ S. Prakash Sinha, "Asylum and International Law”, The Hague : Matinus Nijhott, 1971, hal 95.

${ }^{11}$ M. Alvi Syahrin, "Menakar Edaulatan Negara Dalam Perspektif Keimigrasian”, Jurnal Penelitian Hukum De Jure 18 (1), 2018, hal 43-57. DOI: http://dx.doi.org/10.30641/dejure.2018.V18.43-57
} 
e-ISSN : 2621-4105

Imigran ilegal dapat tidak dipermasalahkan status izin tinggalnya selama berada di Indonesia dalam hal (Pasal 3 ayat (1) Peraturan Dirjen Imigrasi tentang Penanganan Imigran Ilegal):

a. Telah memperoleh Attestation Letter atau surat keterangan sebagai pencari suaka dari United Nations High Comissioner for Refugees ("UNHCR"); atau

b. Berstatus sebagai pengungsi dari UNHCR.

Dalam ketentuan ini, diatur bahwa Imigran Ilegal yang berada di Indonesia dapat tidak dipermasalahkan izin tinggalnya dalam hal telah memperoleh Attestation Letter (surat keterangan sebagai pencari suaka) atau berstatus sebagai pengungsi yang dikeluarkan oleh UNHCR selaku Komisariat Tinggi PBB untuk pengungsi yang berkedudukan di Indonesia. Sehingga, berdasarkan penjelasan kami di atas, dapat dimaknai bahwa seorang imigran ilegal tidak dimungkinkan untuk memperoleh ITAS maupun ITAP, ${ }^{12}$ dikarenakan, yang pertama, imigran ilegal tersebut dikatakan sebagai imigran ilegal adalah karena tidak memiliki dokumen perjalanan yang sah, seperti visa, yang merupakan syarat utama untuk memohonkan ITAS maupun ITAP sebagaimana dimaksud dalam ketentuan Pasal 48 ayat (2) UU 6/2011 bahwa Izin tinggal diberikan kepada orang asing sesuai dengan visa yang dimilikinya.

Yang kedua, bahwa imigran ilegal hanya diperkenankan tinggal sementara waktu di tempat yang telah ditentukan di bawah pengawasan petugas imigrasi, sebelum ditempatkan ke Negara ketiga oleh UNHCR. Hal ini dapat dipahami, dari ketentuan yang terdapat di dalam Formulir Surat Pernyataan Pengungsi Yang Terlampir Dalam Peraturan Direktur Jenderal Imigrasi tentang Penanganan Imigran Ilegal, yang menyebutkan:

"Saya mengerti bahwa Direktorat Jenderal Imigrasi Republik Indonesia mengizinkan pengungsi.... tinggal di tempat yang ditentukan diluar rumah detensi imigrasi selama para pengungsi tersebut dalam proses penempatan ke negara ketiga...."

Oleh karena itu, untuk menjawab pertanyaan Anda yang pertama, bahwa seorang "refugee" atau pengungsi atau imigran ilegal tidak dimungkinkan untuk memperoleh ITAS atau ITAP menurut hukum Indonesia, tidak menjadi persoalan, apakah imigran

12 Heru Susetyo, “Kebijakan Penanganan Internally Displaced Persons (IDPs) di Indonesia dan Dunia Internasional”, Jurnal Hukum Internasional 2 (1), 2004. 
e-ISSN : 2621-4105

ilegal tersebut memperoleh surat keterangan suaka atau status sebagai pengungsi dari UNHCR. ${ }^{13}$

Pengaturan permohonan pewarganegaraan dapat diajukan oleh pemohon jika memenuhi persyaratan sebagaimana diatur dalam Pasal 9 huruf g Undang-Undang Nomor 12 Tahun 2006 tentang Kewarganegaraan Republik Indonesia.

\section{Penanganan Yang Dilakukan Pemerintah Terhadap Keberadaan Imigran Ilegal Di Indonesia}

Penyelundupan manusia dan imigran ilegal mempunyai keterkaitan satu sama lain. Imigran ilegal berhasil masuk ke negara transit maupun negara tujuan tidak selalu membutuhkan kerjasama dengan para agen penyelundup, mereka juga dapat menyelundupkan dirinya sendiri ke negara tujuan tanpa membutuhkan agen penyelundup. Penyelundupan manusia mengakibatkan semakin banyaknya jumlah imigran ilegal. ${ }^{14}$

Indonesia merupakan salah satu negara yang belum melakukan ratifikasi terhadap Konvensi tahun 1951 tentang Status Pengungsi, sehingga sampai saat ini belum ada standart baku mengenai tindakan terhadap pengungsi. Berdasarkan hasil analisis berbagai sumber, bahwa tindakan yang dilakukan pihak keimigrasian di Kantor Imigrasi di Indonesia untuk kasus adanya pengungsi yang terdampar ataupun transit di wilayah lingkungan operasional hukum Indonesia adalah tetap melakukan tindakan keimigrasian berdasarkan peraturan perundang-undangan yang berlaku. ${ }^{15}$

Dalam Peraturan Direktur Jenderal Imigrasi No IMI-1489.UM.08.05 Tahun 2010 tentang Penanganan Imigran Ilegal, dimana setiap pengungsi yang masuk ke Indonesia akan dikenakan tindakan keimigrasian dalam bentuk penahanan sampai status pengungsinya ditetapkan oleh Komisi Tinggi PBB untuk Pengungsi (UNHCR). Namun penentuan status oleh UNHCR dapat memakan waktu sangat lama. Hal Ini berimbas pada munculnya pelanggaran Hak Asasi Manusia (HAM), karena pengungsi bukanlah pelaku kriminal namun ditempatkan pada situasi yang mirip dengan penahanan. Tak heran jika banyak di antara pengungsi yang mengalami tekanan psikologis dan berkeinginan kuat untuk bunuh diri atau kabur dari rumah detensi imigrasi tersebut.

${ }^{13}$ Schloendhadt, "The Business Of Migration: Organized Crime And Illegal Migration In Australia And The Asia Pacific Region”, Adelaide Law Review 1999, hal 21.

${ }^{14}$ Kadarudin, "People Smuggling Dalam Persfektif Hukum Internasional Dan Penegakan Hukumnya Di Indonesia”, Jurnal Perpustakaan, Informasi Dan Komputer : Jupiter 12 (2), 2013, hal 69-70.

${ }^{15}$ Anita Roberts, 2002, “Imigran Illegal Di Indonesia: Dari Perspektif Republik Indonesia”, PT Sinar Grafika, Jakarta, hal 8. 
Penanganan terhadap korban perdagangan orang dan penyelundupan manusia merupakan upaya preventif dan represif dalam rangka mencegah terjadinya tindak pidana perdagangan orang dan penyelundupan manusia. Hal ini merupakan bagian dari upaya penegakan hukum akibat meningkatnya kejahatan internasional atau tindak pidana transnasional, seperti perdagangan orang, penyelundupan manusia. Perdagangan orang juga merupakan salah satu bentuk perlakuan terburuk dari pelanggaran harkat dan martabat manusia dan penyelundupan manusia yang semakin meningkat jumlahnya dan dilakukan melalui jalur laut Indonesia yang sangat terbuka. Oleh karena itu pengaturan hukum diperlukan untuk penanganan perdagangan orang dan penyelundupan manusia di bidang keimigrasian. ${ }^{16}$

Tindakan keimigrasian adalah "tindakan administratif dalam bidang keimigrasian di luar proses peradilan. Dalam pelaksanaan tindakan keimigrasian, untuk menjamin kepastian hukum dan keadilan bagi orang asing yang terkena tindakan keimigrasian". Mengenai tindakan keimigrasian ini telah diatur dalam Pasal 24, 25, 26, 27, 28, 29, 30, 31 dan Pasal 75 Peraturan Pemerintah Republik Indonesia Nomor 31 Tahun 1994 tentang Pengawasan Orang Asing dan Tindakan Keimigrasian.

Kantor Imigrasi Kelas I Malang mempunyai kewenangan dalam menindak persoalan imigran illegal. Kantor imigrasi dapat mengambil tindakan keimigrasian terhadap pelanggaran/penyalahgunaan/penyimpangan keimigrasian dibagi atas dua bentuk, yaitu :

a. Melalui Proses Peradilan

Pejabat imigrasi diangkat sebagai PPNS di bawah koordinasi penyidik POLRI, dengan kewenangan :

1) Melarang orang asing berada di suatu tempat tertentu di Indonesia, atau mengharuskan orang asing berada di suatu tempat yang ditentukan di dalam wilayah Republik Indonesia.

2) Mendeportasi orang asing ke luar wilayah Indonesia.

3) Menempatkan orang asing di karantina Imigrasi, dalam hal:

${ }^{16}$ Aime Zinedine Zack Sumolang, "Penanganan Terhadap Korban Perdagangan Orang Dan Penyelundupan Manusia Menurut Undang-Undang Nomor 6 Tahun 2011 Tentang Keimigrasian”, Lex Et Societatis 3 (2), 2020, hal 16-24. 
e-ISSN : 2621-4105

a) Berada di wilayah Indonesia tanpa memiliki izin keimigrasian yang sah.

b) Dalam rangka menunggu proses pendeportasian.

c) Dalam rangka menunggu keputusan menteri atau pengajuan keberatan yang diajukannya terhadap tindakan keimigrasian yang dikenakan terhadapnya.

b. Tindakan keimigrasian

Merupakan tindakan administratif dalam bidang keimigrasian di luar proses peradilan, yaitu tindakan yang dikenakan terhadap orang asing yang melakukan pelanggaran di bidang keimigrasian tanpa harus menunggu keputusan dari proses peradilan. Berdasarkan data yang diperoleh, faktor-faktor yang membuat orang asing masuk ke wilayah Indonesia secara tidak sah (imigran gelap) dikarenakan adanya situasi politik atau stabilitas politik di negaranya sudah sangat tidak kondusif dan mengancam hidupnya, atau mengganggu dalam pemenuhan kebutuhan hidupnya Dalam masalah ini pihak keimigrasian melakukan penanganan imigran gelap dengan melakukan karantina dan deportasi.

Untuk mengetahui ada tidaknya imigran illegal, kantor imigrasi melakukan pengawasan baik dalam hal administratif maupun pengawasan lapangan sesuai Petunjuk DirJenim Nomor F-33.II.01.10 Tahun 1995 Tentang Tata Cara Pengawasan Orang Asing. Pengawasan administratif dilakukan melalui penelitian surat-surat atau dokumen, berupa pencatatan, pengumpulan, pengolahan data dan penyajian maupun penyebaran informasi secara manual dan elektrik, tentang lalu lintas keberadaan dan aktivitas orang asing.

\section{E. PENUTUP}

Berdasarkan pembahasan yang telah diuraikan dimuka maka dapat disimpulkan bahwa Indonesia masih adanya kekosongan hukum karena belum ada aturan yang komprehensif dalam mengatur para pengungsi dan pencari suaka dalam hukum positif di Indonesia telah melemahkan koordinasi antar instansi di lapangan. Bahkan dalam banyak kasus Pemda merasa keberatan menerima tambahan beban dengan masuknya orang asing (pengungsi) di wilayah. Perbedaan tajam antara kultur daerah dan pengungsi sangat potensial menimbulkan konflik sosial. Selain itu seandainya terjadi proses asimilasi antara pengungsi dengan warga setempat justru menimbulkan beban baru karena anak- 
e-ISSN : 2621-4105

anak yang ada akibat asimilasi tersebut tidak dibawa serta saat repatriasi atau resetlement. Upaya-upaya yang dilakukan oleh Pemerintah Indonesia dalam menangani imigran ilegal di Indonesia adalah dengan membantu dalam mengatur pergerakan imigran ilegal melalui penyediaan layanan bantuan bagi orang yang ditangkap dalam hal ini adalah imigran ilegal asal negara-negara luar dalam perjalanan mereka oleh pihak yang berwajib di Indonesia. Layanan-layanan tersebut meliputi bimbingan/konseling, perawatan medis, makanan, penampungan, pelatihan keterampilan dasar dan bantuan dalam mengajukan permohonan suaka atau pemulangan sukarela. Perlunya political will dari pemerintah untuk segera menjadi pihak pada Konvensi 1951 dan Protokol 1967 sangat diharapkan. Penanganan persoalan pengungsi harus mengedepankan prinsip individual rights model yang memperlihatkan prinsip keamanan manusia (human security). Hal ini penting agar tercipta hubungan bilateral yang baik antara negara asal pengungsi (country of origin/home country) dengan negara tujuan pengungsi (the host country).

\section{DAFTAR PUSTAKA}

\section{Buku}

Achmad, Romsan, dkk, 2003, "Pengantar Hukum Pengungsi Internasional: Hukum Internasional dan Prinsip-Prinsip Perlindungan Internasional”, Percetakan Sanic Offset, Bandung.

Anita, Roberts, 2002, "Imigran Illegal Di Indonesia: Dari Perspektif Republik Indonesia”, PT. Sinar Grafika, Jakarta.

IOM, 2009, "Buku Petunjuk Bagi Petugas Dalam Rangka Penanganan Kegiatan Penyelundupan Manusia dan Tindak Pidana yang Berkaitan dengan Penyelundupan Manusia, International Organization for Migration (IOM)", Jakarta.

Kusumaatmadja, Mochtar, 1976, "Pengantar Hukum Internasional”, Jakarta : Bina Cipta. Soekanto, Soerjono, 2001, "Penelitian Hukum Normatif", Rajawali Pers, Jakarta.

S. Prakash Sinha, 1971, “Asylum and International Law”, The Hague : Matinus Nijhott.

\section{Jurnal}

Aime Zinedine Zack Sumolang, "Penanganan Terhadap Korban Perdagangan Orang Dan Penyelundupan Manusia Menurut Undang-Undang Nomor 6 Tahun 2011 Tentang Keimigrasian", Lex Et Societatis 3 (2), 2020.

Eka Annisa Salam, "Penegakan Hukum Tindak Pidana Penyelundupan Manusia (People Smuggling) Dalam Hukum Positif Indonesia", Jurnal Pemuliaan Hukum 3 (1) 2020 , 
Evi Masrifatin Silvia, “Upaya Penanggulangan Kasus Perdagangan dan Penyelundupan Manusia Sebagai Kejahatan Transnasional Terorganisir",Journal Inicio Legis 1 (1), 2020.

Kadarudin, "People Smuggling Dalam Persfektif Hukum Internasional Dan Penegakan Hukumnya Di Indonesia”, Jurnal Perpustakaan, Informasi Dan Komputer : Jupiter 12 (2), 2013.

Heru Susetyo, “Kebijakan Penanganan Internally Displaced Persons (IDPs) di Indonesia dan Dunia Internasional”, Jurnal Hukum Internasional 2(1), 2004.

M.Alvi Syahrin, "Menakar Edaulatan Negara Dalam Perspektif Keimigrasian”, Jurnal $\begin{array}{llllll}\text { Penelitian Hukum } & & \end{array}$ DOI: http://dx.doi.org/10.30641/dejure.2018.V18.43-57

Muhar Junef, "Kajian Praktik Penyelundupan Manusia di Indonesia”, Jurnal Penelitian Hukum De Jure, 20 (1), 2020.

Schloendhadt, "The Business Of Migration: Organized Crime And Illegal Migration In Australia And The Asia Pacific Region", Adelaide Law Review, 1999.

Suryani, Suhirwan, Rudy A. G. Gultom, "Strategi Pangkalan TNI AL Dumai Dalam Menghadapi Penyelundupan Manusia Di Perbatasan Laut Dumai Dan Selat Malaka", Jurnal Peperangan Asimetris 4 (3), 2018.

\section{Internet}

https://www.unhcr.org/id/unhcr-di-indonesia, 